\title{
Using molluscan assemblages from paleotsunami deposits to evaluate the influence of topography on the magnitude of late Holocene mega-tsunamis on Ishigaki Island, Japan
}

\author{
Akihisa Kitamura ${ }^{1,2^{*}}$, Mami Ito $^{3}$, Ryoya Ikuta ${ }^{1,2}$ and Masayuki Ikeda ${ }^{1,2}$
}

\begin{abstract}
Four ancient tsunami deposits were identified in a trench excavated on Ishigaki Island, Okinawa, Japan. Three of the tsunami deposits (T-I, T-II, and T-IV) consist of calcareous sand beds, whereas the other (T-III, located stratigraphically between T-II and T-IV) consists of boulders. Deposit T-I was caused by a tsunami in $1771 .{ }^{14} \mathrm{C}$ dating, together with the elevations of the landward margins of these sandy tsunami deposits, suggests that tsunamis II and IV were similar in size to the 1771 tsunami, although the influence of local topographic features on the magnitudes of tsunamis has not yet been examined. This study reconstructs the local topographic features by comparing the molluscan assemblages incorporated within the tsunami deposits with those in recent beach deposits. The presence of species that inhabit the intertidal zone in lagoonal settings in all the assemblages indicates that the present-day shallow lagoon has been present off the study area since the occurrence of tsunami T-IV, which supports the previous hypothesis that the magnitudes of the 1771 tsunami and tsunamis II and IV were similar. These molluscan assemblages also suggest that a high relative abundance of large, heavy mollusc shells is a feature of the paleotsunami deposits in the coastal lowlands found along the shallow coral lagoons.
\end{abstract}

Keywords: 1771 tsunami, Ancient tsunami deposit, Reef system, Southern Ryukyu Islands, Mollusc

\section{Introduction}

Paleotsunami research based on coastal geological records is a useful approach to the detection of high-magnitude, low-frequency tsunami events along subduction zones (e.g., Atwater 1987; Minoura et al. 2001; Nanayama et al. 2003; Cisternas et al. 2005; Monecke et al. 2008; Shishikura et al. 2010; Ishimura and Miyauchi 2015; Nelson et al. 2015; Kitamura 2016; Inoue et al. 2017). Although previous paleotsunami research along the Ryukyu Trench has examined coralline boulders (herein, "tsunami boulders") (Kawana and Nakata 1994; Goto et al.

\footnotetext{
* Correspondence: kitamura.akihisa@shizuoka.ac.jp

${ }^{1}$ Faculty of Science, Shizuoka University, 836 Ohya Suruga-ku, Shizuoka 422-8529, Japan

${ }^{2}$ Center for Integrated Research and Education of Natural hazards, Shizuoka University, 836 Ohya, Suruga-ku, Shizuoka 422-8529, Japan

Full list of author information is available at the end of the article
}

2010; Araoka et al. 2013), Ando et al. (2018) recently identified three sandy tsunami deposits (T-I, T-II, and T-IV) and a layer of buried tsunami boulders (T-III) in a trench on Ishigaki Island (Figs. 1, 2, and 3). Based on their ${ }^{14} \mathrm{C}$ ages and the elevations of the landward margins of these sandy tsunami deposits, the authors estimated that tsunamis II and IV were similar in size to the 1771 tsunami (tsunami deposit T-I), assuming that these paleotsunamis were generated at the same location and by the same mechanism.

It is widely accepted that on coral reefs, the magnitude of tsunamis can be strongly influenced by the morphology of the reef crest and beach ridge, both of which reduce the tsunami's energy. For example, on Taketomi Island, located just $5 \mathrm{~km}$ south of Ishigaki Island, damage from the 1771 tsunami was reportedly slight (Makino 1968) (Fig. 1). Taketomi Island is protected by 


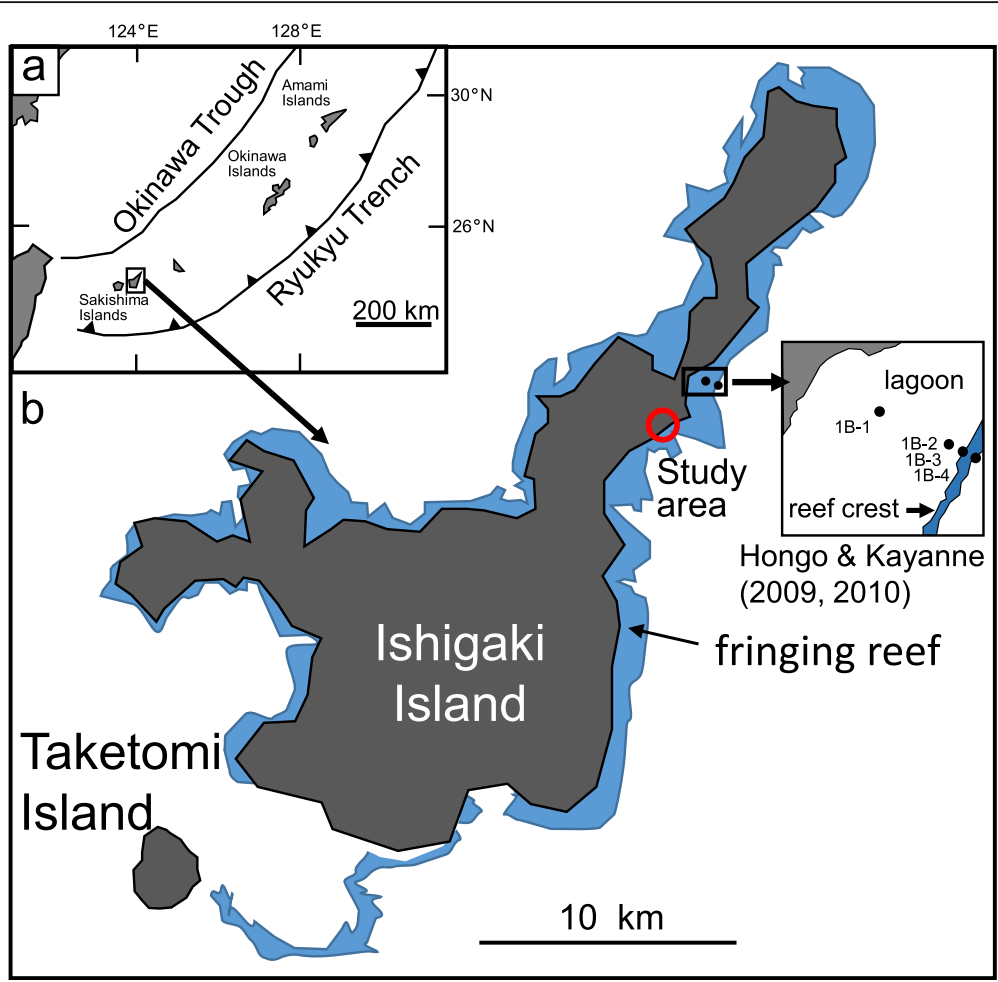

Fig. 1 Study location. a Plate boundaries around the southern Ryukyu Islands (after Ando et al. 2009). b Ishigaki Island, showing the location of the study area (after Goto et al. 2010)
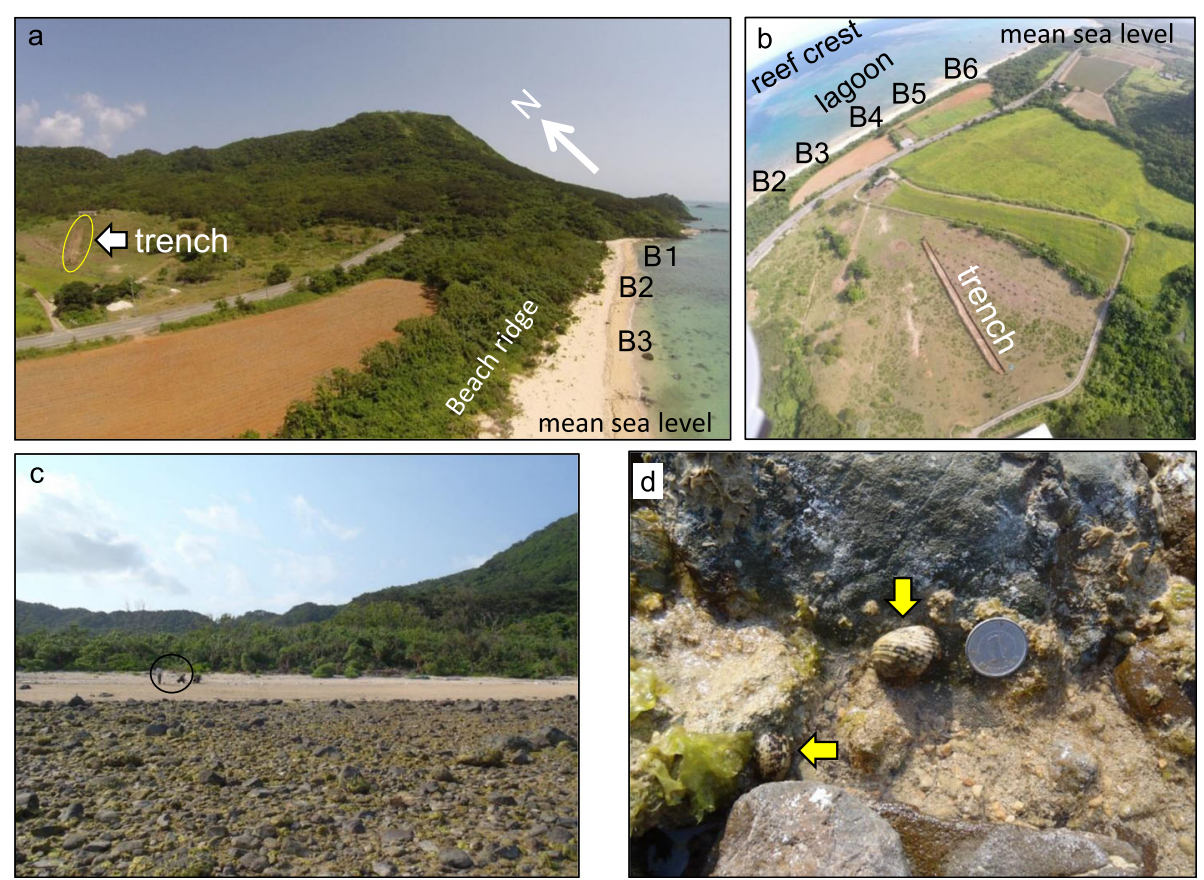

Fig. 2 a Photograph of the trench, showing sampling sites B1-B3. b Photograph of the trench, showing sampling sites B2-B6. c Photograph of the coastal area at site B2. The circle is around two persons. $\mathbf{d}$ Two Nerita squamulata individuals (arrows) at site B2 


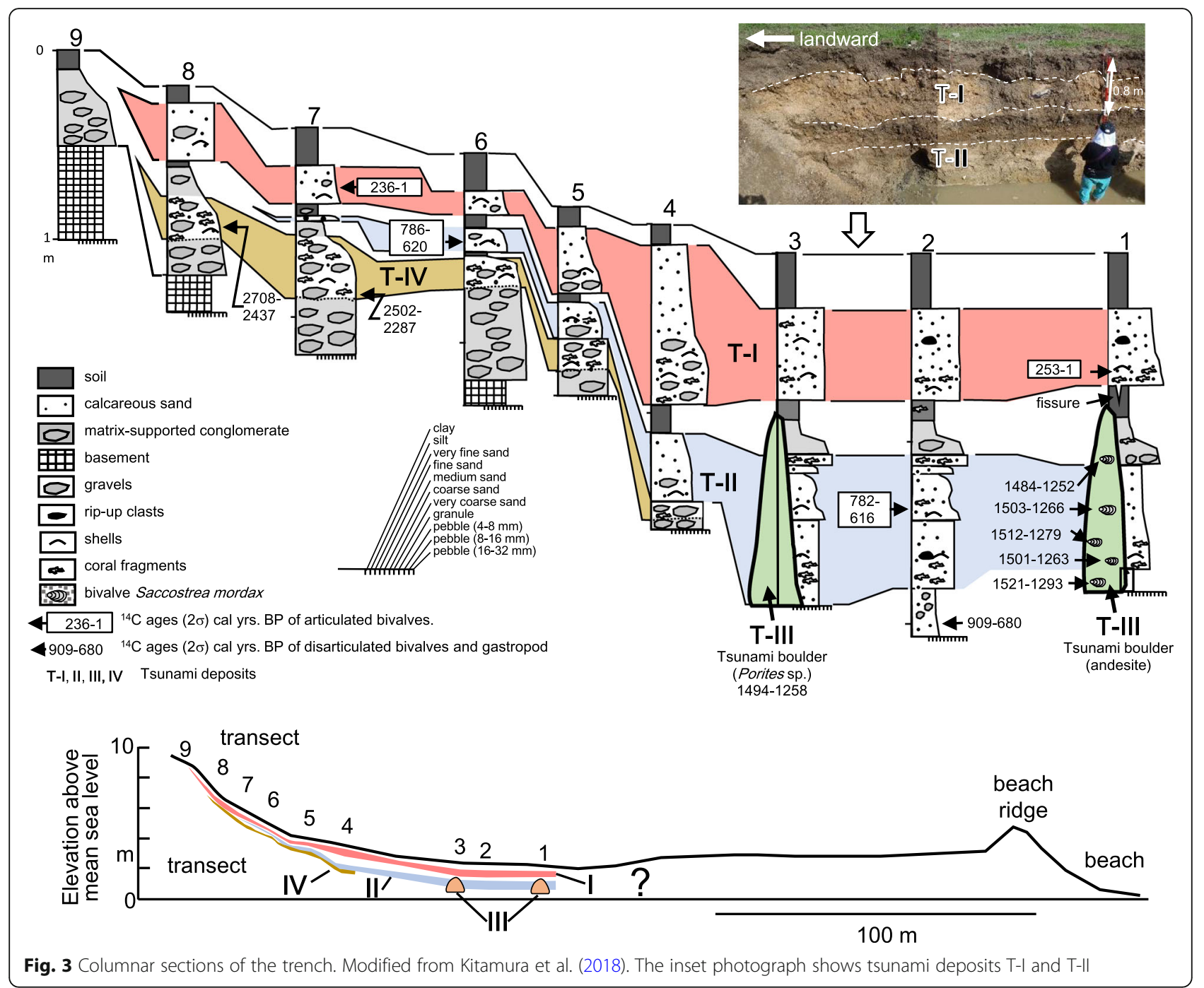

Sekisei Lagoon, which is 10-20 m deep and has formed within the barrier reefs (Kan and Kawana 2006) between the southwestern coast of Ishigaki Island and the eastern coast of Iriomote Island, and includes Taketomi and Kuro Islands (Machida et al. 2001). It is probable that this large lagoon greatly reduced the tsunami's energy before it reached Taketomi Island (Goto et al. 2010). Therefore, the examination of local geomorphological features is essential when evaluating Ando et al.'s (2018) estimate, although, to the best of our knowledge, there have been no previous studies of the local geomorphology.

We collected molluscan shells from tsunami deposits T-I, T-II, and T-IV during the survey reported by Ando et al. (2018), although these specimens have not been analyzed until now. Here, we examine the molluscan assemblages preserved within these tsunami deposits and also those present in recent beach deposits, with the aim of reconstructing the local geomorphological features. Because molluscan species are strongly controlled by the substrate type, which is related in turn to the hydrodynamic conditions (e.g., Kondo et al. 1998), the species compositions provide information on the shallow marine environments in the study area. Our data provide a unique opportunity to evaluate the magnitudes of tsunamis T-I, T-II, and T-IV and the utility of biological proxies in paleotsunami research.

\section{Previous studies of molluscan assemblages within tsunami deposits}

Several studies have examined molluscan assemblages within tsunami deposits in coastal lowlands (Morales et al. 2008; Reinhardt et al. 2012; Vött et al. 2011; Goff et al. 2012; Engel et al. 2016; Mannen et al. 2018) and shallow-water inshore areas (Fujiwara et al. 2000; Reinhardt et al. 2006; Donato et al. 2008). Many studies have found that these molluscan assemblages are characterized by a mixture of mollusc shells from a wide range of habitats (e.g., Fujiwara et al. 2000; Donato et al. 2008; 
Morales et al. 2008; Richmond et al. 2011). This is also commonly true of microfossils, such as foraminifera (e.g., Nanayama and Shigeno 2006; Sugawara et al. 2009; Rubin et al. 2017) and diatoms (e.g., Sawai et al. 2009; Goff et al. 2012). Kortekaas and Dawson (2007) and Donato et al. (2008) found that molluscan assemblages are characterized by a high percentage of articulated bivalve shells if the sediment source includes a bivalve habitat. However, Fujiwara et al. (2014) examined the species composition and occurrence of molluscan shells in an onshore tsunami deposit formed by the 2011 Tohoku-oki tsunami, and reported a low percentage of articulated bivalve shells.

Recently, Kitamura et al. (2018) analyzed the oxygen isotope profiles of two articulated marine bivalves from tsunami deposit T-II in the present study area. These shells were tightly closed and empty and yielded the same calibrated ages of 920-620 cal. years BP, indicating that the shells were transported and buried alive by the tsunami (Ando et al. 2018). The isotopic analysis showed that tsunami deposit II was caused by a tsunami during the autumn (Kitamura et al. 2018). A combination of radiometric dating and analysis of the $\delta^{18} \mathrm{O}$ profiles of articulated bivalves can provide important chronological constraints when examining paleotsunami events.

Tsunami deposits from the 2011 Tohoku-oki tsunami have been examined from many parts of the 900-km-long coastline between southwestern Hokkaido and the northern Boso Peninsula. No marine mollusc shells were detected in most areas (Szczuciński et al. 2012; Takashimizu et al. 2012; Kitamura 2016), except in one area on the Sendai Plain (Fujiwara et al. 2014). Sugawara et al. (2014) suggested that the absence of marine fossils can be explained if the tsunami caused a significant amount of erosion on the beach and in the coastal forest areas, but the erosion was minor on the offshore seafloor.

\section{Study area}

The Ryukyu Islands are located along the Ryukyu Trench, which marks the convergent boundary between the Eurasian and Philippine Sea plates. They are divided into three island groups, from north to south: the Amami, Okinawa, and Sakishima Islands (Fig. 1). According to historical descriptions, the area has experienced nine tsunamis since 1644 AD (Watanabe 1985). The 1771 tsunami was an extremely large event, but historical documents show that it damaged only a restricted area, the Sakishima Islands, including Ishigaki Island (Goto et al. 2010). Based on the clast sizes and spatial distributions of boulders on the reefs of the Ryukyu Islands, Goto et al. (2013) suggested that large tsunamis have struck locally but repeatedly around the Sakishima Islands, but not around the Amami and Okinawa Islands, at least during the past 2300 years.
Historical documents show that the coastal areas of Ishigaki Island, located in the southern Ryukyu Islands, Japan (Fig. 1), were inundated by a mega-tsunami (the 1771 tsunami) at $\sim$ 08:00 (Japan time zone) on 24 April 1771 after a large earthquake. The tsunami had a maximum wave height of $\sim 30 \mathrm{~m}$ (Iwasaki 1927; Goto et al. 2010) and transported tsunami boulders of up to $10 \mathrm{~m}$ in diameter (Makino 1968; Shimajiri 1988; Goto et al. 2010). The ${ }^{14} \mathrm{C}$ dates of other tsunami boulders from the southern Ryukyu Islands were examined by Kawana and Nakata (1994) and Goto et al. (2010). Araoka et al. (2013) recently estimated that large tsunamis have occurred at recurrence intervals of 150-400 years since at least 2400 years ago.

More recently, Ando et al. (2018) identified three sandy tsunami deposits (T-I, T-II, and T-IV) and buried tsunami boulders (T-III) in a trench extending inland from the seaward-facing slopes behind a beach ridge on Ishigaki Island. The slopes face a barrier reef lagoon located in the northeastern coastal area of Ishigaki Island. Based on their ${ }^{14} \mathrm{C}$ ages, deposit T-I was caused by the 1771 tsunami and the three older tsunami deposits (T-II, T-III, and T-IV) formed at 920-620, 1670-1250, and between 2700-2280 and 1670-1250 cal. years BP, respectively (Ando et al. 2018).

Ando et al. (2018) have inferred that the boulders of deposit T-III rest on a stratigraphic horizon lower than, but projecting above, that of deposit T-II. Because the bases of the two boulders could not be observed (they were submerged in groundwater), the stratigraphic relationship between these boulders and deposit T-IV is unknown. However, based on the ${ }^{14} \mathrm{C}$ ages, deposit T-III is younger and stratigraphically higher than deposit T-IV (Fig. 3).

The elevations of the landward margins of the sandy tsunami deposits T-I, T-II, and T-IV are up to 9, 6, and $8 \mathrm{~m}$ above mean sea level (MSL), respectively (Fig. 3). Based on the ages of these deposits, the mean uplift rate (Yokoyama et al. 2016), and the tidal range, Ando et al. (2018) calculated that the elevations of the land margins associated with deposits I, II, and IV during their deposition were 7.7-9.9 $\mathrm{m}, 3.9-6.7 \mathrm{~m}$, and 3.9-8.5 $\mathrm{m}$ above MSL, respectively. The authors concluded that tsunamis II and IV were similar in size to the 1771 tsunami, assuming that these paleotsunamis were generated at the same location and by the same mechanism.

The study trench was located on the seaward-facing slopes behind a beach ridge (Figs. 1, 2, and 3). The beach ridge faces a reef lagoon that is protected by a reef crest. Hongo and Kayanne (2009) analyzed four drill cores (IB-1 to IB-4; Fig. 1) collected from the same lagoon and a reef crest located $4 \mathrm{~km}$ northeast of the study area and concluded that the reef crest had reached sea level and that sea level had stabilized at or around its present level by ca. 7000-6000 years BP, with the burial of the lagoon beginning after that time. On the basis of the 
stratigraphic distributions of the corals in core IB-3, Hongo and Kayanne (2010) reported that the relative sea-level peaked at $\sim 3.0 \pm 2.5 \mathrm{~m}$ above the present-day MSL at ca. 5000 cal. years BP and gradually decreased thereafter to the level of the present-day MSL.

The shoreface deposits in the study area consist of coarse calcareous sand containing fragments of corals and molluscs. Many coralline and andesitic boulders are present on the shoreface and in the lagoon (Fig. 2c). A 4-m-high beach ridge has developed $30 \mathrm{~m}$ landward of the shoreline at MSL and consists of fine calcareous sand. Behind the beach ridge, the 150-m-wide lowland connects to a $7.5 \%$ slope (Figs. $2 \mathrm{a}$ and 3 ). The lagoon is $\sim 1320 \mathrm{~m}$ wide and is less than $4.0 \mathrm{~m}$ deep (Hongo and Kayanne 2009). The mean tidal range in the area around Ishigaki Island is $\sim 2 \mathrm{~m}$ (Goto et al. 2010). Typhoons commonly affect the study area during the summer.

\section{Methods/Experimental}

We collected shell specimens by hand from a surface area of $5 \mathrm{~m}^{2}$ on beach berms ( $2 \mathrm{~m}$ above MSL) at six sites (B1-B6) during the period 18-20 April, 2014 (Fig. 2a, b). We also collected molluscs from tsunami deposits T-I, T-II, and T-IV from a trench excavated in 2014, using two methods. Method 1 involved the sampling of surface exposures in the walls of the trench. The total sampling area was $43.9 \mathrm{~m}^{2}$ for the T-I deposits, $37.4 \mathrm{~m}^{2}$ for the T-II deposits, and $10.3 \mathrm{~m}^{2}$ for the T-IV deposits. Method 2 involved sampling the molluscs from the $>2 \mathrm{~mm}$ fractions in blocks of sediment $(1.6-6.5 \mathrm{~kg}$ ) collected from four sites. Methods 1 and 2 are suitable for recording rare and large specimens, and small specimens, respectively. The assemblages in tsunami deposits T-I, T-II, and T-IV are hereafter referred to as assemblages T-I, T-II, and T-IV and were further subdivided into T-I-1 and T-I-2, T-II-1 and T-II-2, and T-IV-1 and T-IV-2, indicating the use of method 1 or method 2 for sample collection, respectively. The taxonomic identification of molluscs was based on Okutani (2000). For the disarticulated or fragmented shells that retained the hinge feature (the beak or umbo portion) on the shell, a separate valve was counted as one individual. Each specimen from assemblages T-I, T-II, and T-IV was weighed, and we also measured the length, height, and width of the shells to the nearest $0.1 \mathrm{~mm}$ using digital calipers.

\section{Results}

A total of 627 individuals and 53 taxa were identified in the recent assemblages (Additional file 1: Table S1 and Additional file 2: Table S2). The dominant species in the assemblages at sites B1 to B5 were the gastropods Nerita (Theliostyla) squamulata and Nerita (Theliostyla) albicilla and the bivalves Barbatia (Abarbatia) lima, Fragum fragum, and Atactodea striata, whereas the assemblage at site B6 was exclusively dominated by $A$. striata (66.1\%) (Fig. 4). The percentage of articulated bivalve shells ranged from $0 \%$ (sites B1, B3, B4, and B5) to 4\% (B2; Fig. 4). The assemblages consisted mainly of species that inhabit rocky, sandy, or muddy bottoms in the intertidal zone and weighed less than $5 \mathrm{~g}$ (Fig. 4). The heaviest specimen was the bivalve Tridacna maxima, with a shell weight of $90 \mathrm{~g}$. Many living individuals of $N$. squamulata and $N$. albicilla were observed on rocky substrates in the intertidal zone at site B2 (Fig. 2c, d).

There were differences in the species compositions of assemblages T-I, T-II, and T-IV collected with the two sampling methods (Fig. 4; Additional file 3: Table S3, Additional file 4: Table S4, Additional file 5: Table S5, Additional file 6: Table S6). The dominant species in assemblage T-I-1 were F. fragum, F. unedo, and A. striata, whereas the dominant species in assemblage T-I-2 were $F$. fragum and F. loochooanum. The dominant species in assemblage T-II-1 were F. fragum, F. unedo, and Mactra maculate, whereas the dominant species in assemblage T-II-2 were Epicodakia bella, F. loochooanum, and F. unedo. The dominant species in assemblage T-IV-1 were F. fragum, F. unedo, T. maxima, A. striata, and Glycydonta marica, whereas the dominant species in assemblage T-IV-2 were F. loochooanum and F. unedo. The percentages of articulated bivalve shells were less than 1\%, except in assemblage T-II-1 (7\%) (Fig. 4).

There were no differences in the relative abundances of organisms from specific habitat types among assemblages T-I, T-II, and T-IV (Fig. 4). These habitats were mainly the rocky intertidal zone and the sandy or muddy bottom of the intertidal zone (Fig. 4). The relative abundances of subtidal species were slightly higher in assemblages T-I-1, T-I-2, and T-IV-2 than in the other assemblages. The shell weight of the dominant specimens collected with method 1 (mainly $>1.0 \mathrm{~g}$ ) was significantly greater than that of specimens collected with method 2 (mainly < 0.5 g) (Fig. 4). We believe that the relatively high abundance of $F$. loochooanum in the assemblages obtained with method 2 can be explained by their smaller shells, and confirm that the combination of these two methods is essential to ensure that reliable fossil data are obtained.

The shell-weight distributions of the specimens collected from the tsunami deposits with methods 1 and 2 are shown in Fig. 5. We observed no systematic landward trends (such as landward reductions) in shell weight.

The molluscan abundances obtained with method 1 (number $/ \mathrm{m}^{2}$ ) are shown for each 10-m-long section of the trench (Fig. 6). The abundances in deposit T-II were much lower than those in deposits T-I and T-IV. We also observed no systematic landward trends (such as landward reductions) in abundance. However, the molluscan abundances obtained with method 2 (number/ $\mathrm{kg}$ ) 


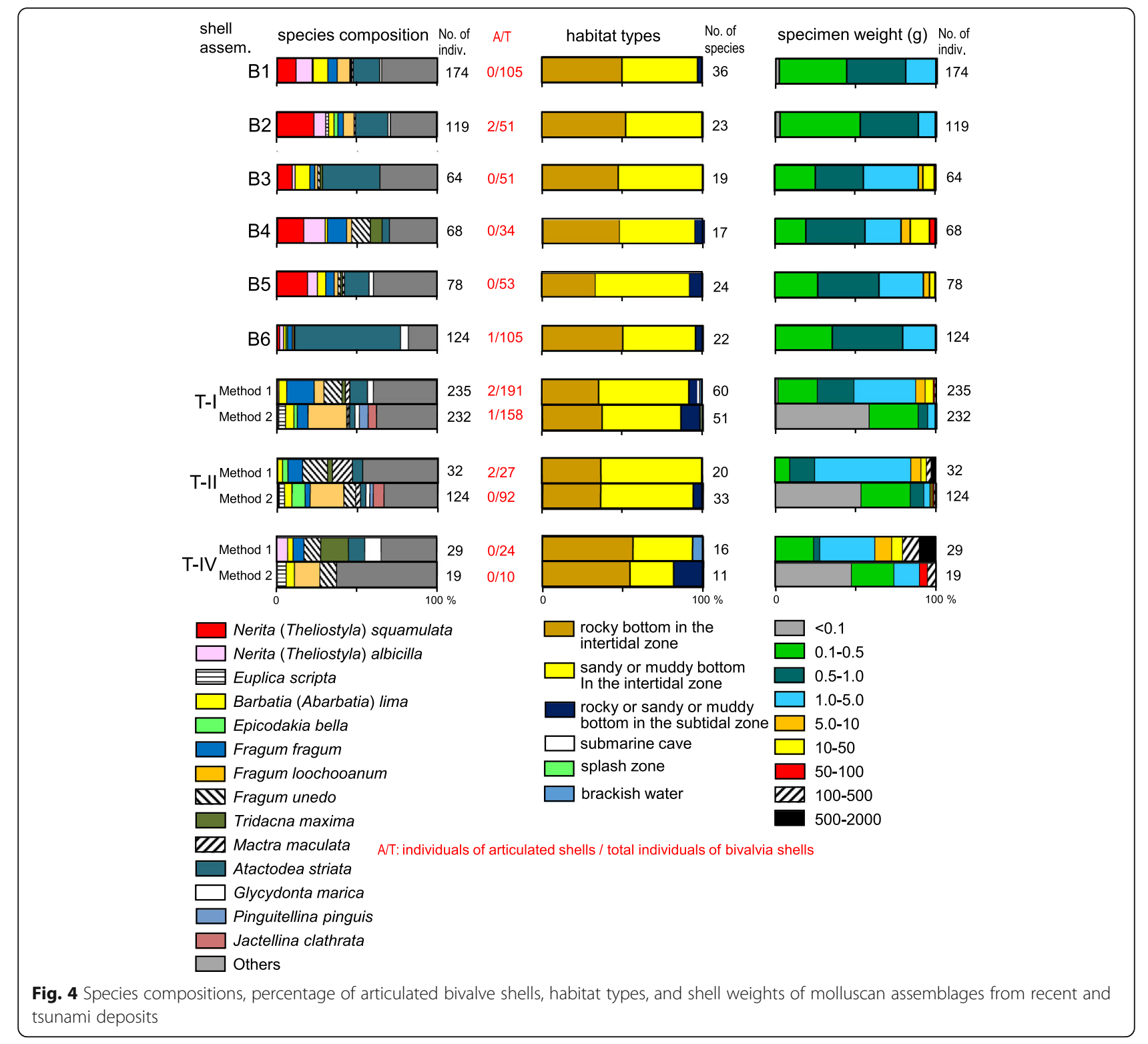

showed that the abundances in deposit T-II were nearly the same as those in deposit T-I and were significantly greater than the abundances in deposit T-IV (Fig. 6).

\section{Discussion}

\section{Influence of local topographic features on tsunami} magnitude

As noted above, the species compositions of mollusc assemblages provide information on the shallow marine environments offshore from the study area. The bivalves $F$. fragum, A. striata, and F. unedo were the dominant species found in the assemblages from tsunami deposits T-I, T-II, and T-IV and were also abundant in the recent assemblage (Fig. 4). Both F. fragum and $F$. unedo are burrowing photosymbiotic bivalves (Ohno et al. 1995). The bathymetric range of the former is the lower intertidal zone to a depth of $20 \mathrm{~m}$, whereas that of the latter is the lower intertidal zone (Okutani 2000). Atactodea striata inhabits sandy substrata in the intertidal zone of lagoons protected by reef crests (Kondo and Yokogawa 2001). The species occurs over a wide depth range within the intertidal zone, with peak abundances near the mean tide level (Takada et al. 2002). On the basis of the ecology of these species, we conclude that the lagoonal conditions seaward of the study area have not changed significantly since the occurrence of tsunami T-IV, which is consistent with the interpretation of cored sediments near the study area by Hongo and Kayanne (2009). Therefore, differences in the elevations of the land extent of tsunami deposits I (7.7-9.9 m above MSL), II (3.9-6.7 $\mathrm{m}$ above MSL), and IV (3.9-8.5 $\mathrm{m}$ above MSL) during their deposition, which 


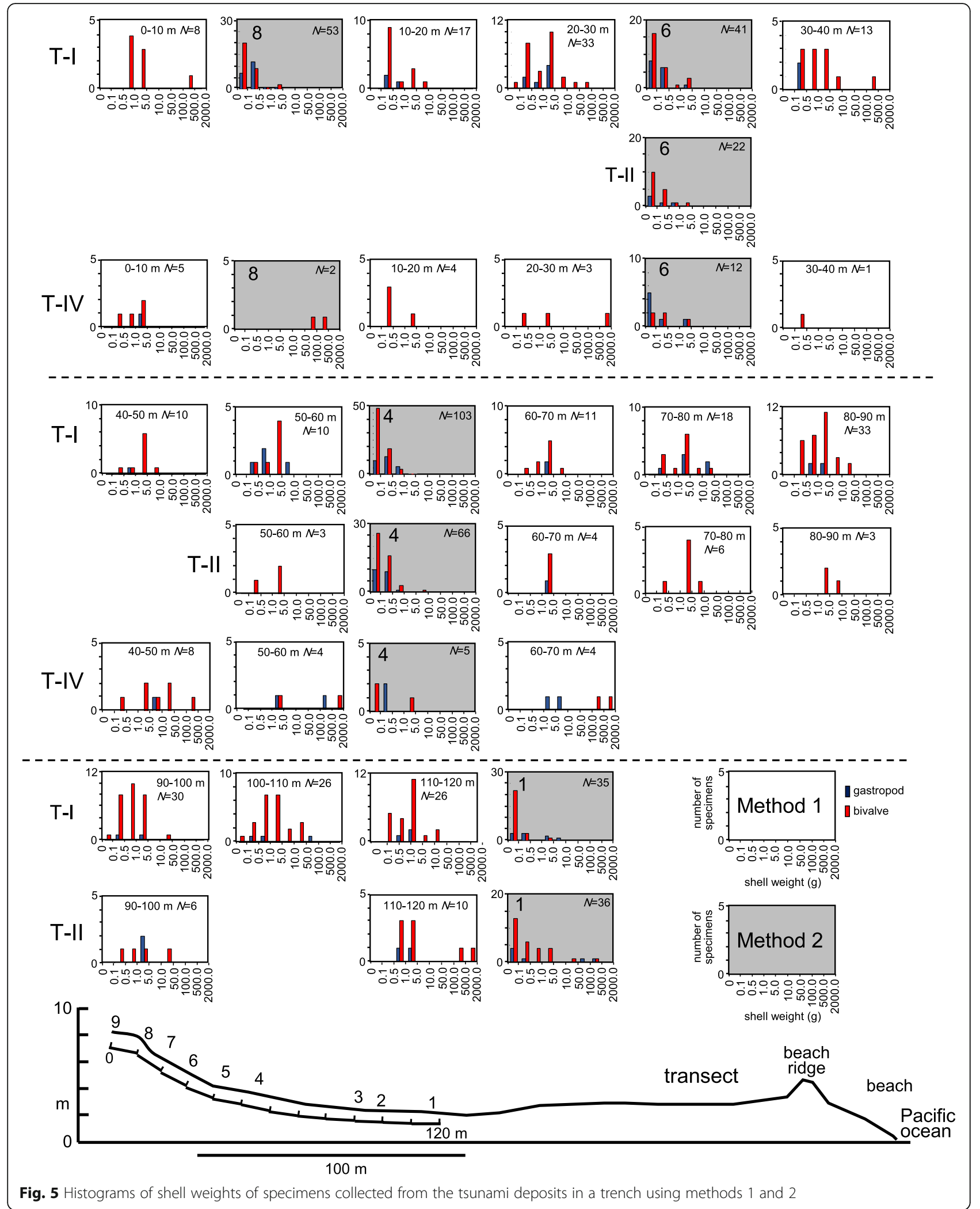




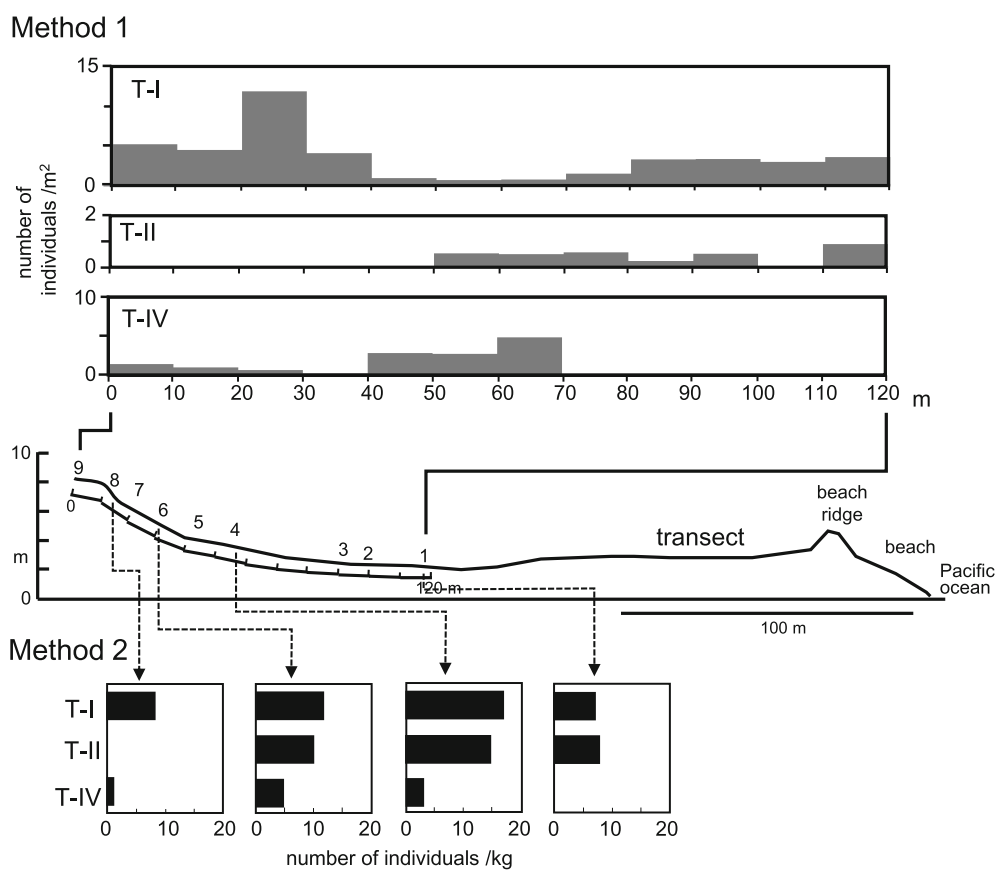

Fig. 6 Molluscan abundances in the tsunami deposits obtained in a trench using methods 1 and 2

were estimated by Ando et al. (2018), were not influenced by the presence or absence of the reef crest. This confirms Ando et al.'s (2018) interpretation that tsunamis II and IV were similar in size to the 1771 tsunami. The present-day lagoonal conditions have persisted since the occurrence of tsunami T-IV, allowing tsunami deposits T-I, T-II, and T-IV to be used as analogues for modeling future tsunamis in the study area.

\section{Utility of biological proxies in the study of paleotsunami deposits}

We examined the features of the molluscan assemblages associated with three sandy tsunami deposits by comparing them with a recent assemblage. As noted above, previous studies have identified two key features of the molluscan assemblages found in tsunami deposits: (1) the mixture of mollusc shells is from a wide range of habitats; and (2) the percentage of articulated bivalve shells is high if the sediment source area incorporates a bivalve shell habitat. The former feature is inconsistent with our data, insofar as there were no distinct differences in the patterns of habitat types among assemblages T-II-1, T-II-2, and T-VI-1 and the recent assemblages. However, the lagoon off the study area is less than $4 \mathrm{~m}$ deep, so that the environmental heterogeneity in the source area of the molluscan shells may be low. In this situation, it is likely that a wide range of habitats of molluscan shells is not a valid index for the molluscan assemblages in paleotsunami deposits. The very low percentage of articulated bivalve shells in assemblages T-I, T-II, and T-IV (Fig. 4) indicates that the latter feature is not universal.

However, the relative abundance of heavy shells (mainly $>1.0 \mathrm{~g}$ ) was significantly greater in assemblages T-I-1, T-II-1, and T-IV-1 than in the recent assemblages (Fig. 4). Because strong hydrodynamic flows are required to entrain large, heavy shells, we propose that the relative abundance of large, heavy shells in the molluscan assemblages of paleotsunami deposits is a valid indicator of tsunami strength in coastal lowlands inside shallow coral lagoons.

\section{Conclusions}

A comparison of the molluscan assemblages from three sandy tsunami deposits and from a recent beach deposit on Ishigaki Island, southwest Japan, showed that the conditions in the reef systems seaward of the study area have remained unchanged since the occurrence of tsunami T-IV. This confirms that the magnitudes of the 1771 tsunami and tsunamis II and IV were similar. Our data indicate that the proportion of large, heavy shells in the molluscan assemblages in paleotsunami deposits is a valid index of tsunami strength on coastal lowlands inside shallow coral reef lagoons.

\section{Additional files}

Additional file 1: Table S1. List of molluscan specimens collected at sites B1-B6. R: right valve; L: left valve. (XLSX $15 \mathrm{~kb}$ )

Additional file 2: Table S2. List of shell sizes and shell weights of specimens collected at sites B1-B6. (XLSX $41 \mathrm{~kb})$ 
Additional file 3: Table S3. List of molluscan specimens collected from the tsunami deposits with method 1. (XLSX 19 kb)

Additional file 4: Table S4. List of shell sizes and shell weights of specimens collected from the tsunami deposits with method 1. (XLSX $27 \mathrm{~kb}$ )

Additional file $\mathbf{5}$ Table $\mathbf{S 5}$. List of molluscan specimens collected from the tsunami deposits with method 2. (XLSX $16 \mathrm{~kb}$ )

Additional file 6 Table S6. List of shell sizes and shell weights of specimens collected from the tsunami deposits with method 2. (XLSX $30 \mathrm{~kb})$

\section{Abbreviations}

MSL: Mean sea level

\section{Acknowledgements}

We thank Dr. Masataka Ando, Dr. Toshiaki Masuda, Imai Takafumi, and Toshiyuki Chinen for our survey on Ishigaki Island. We acknowledge constructive reviews from anonymous reviewers for improvements. This study was supported by the Integrated Center for Education and Research of Natural Hazards, Shizuoka University, and Grants-in-Aid (26287126) awarded by the Japan Society for the Promotion of Science.

\section{Funding}

This study was funded by the Integrated Center for Education and Research of Natural Hazards, Shizuoka University, and Grants-in-Aid (26287126) awarded by the Japan Society for the Promotion of Science.

\section{Authors' contributions}

AK conceived designed, collected samples and identified specimens of molluscs samples. Mlt analyzed molluscs samples. RI and Mlk collected samples and examined evaluation of tsunami wave height. All authors read and approved the final manuscript.

\section{Competing interests}

The authors declare that they have no competing interests.

\section{Publisher's Note}

Springer Nature remains neutral with regard to jurisdictional claims in published maps and institutional affiliations.

\section{Author details}

${ }^{1}$ Faculty of Science, Shizuoka University, 836 Ohya Suruga-ku, Shizuoka 422-8529, Japan. ${ }^{2}$ Center for Integrated Research and Education of Natural hazards, Shizuoka University, 836 Ohya, Suruga-ku, Shizuoka 422-8529, Japan. ${ }^{3}$ Graduate School of Science, Shizuoka University, 836 Ohya Suruga-ku, Shizuoka 422-8529, Japan.

Received: 17 November 2017 Accepted: 27 July 2018 Published online: 14 August 2018

\section{References}

Ando M, Kitamura A, Tu Y, Ohashi Y, Imai T, Nakamura M, Ikuta R, Miyairi Y, Yokoyama Y, Shishikura M (2018) Source of high tsunamis along the southernmost Ryukyu trench inferred from tsunami stratigraphy. Tectonophysics 722:265-276.

Ando M, Nakamura M, Matsumoto T, Furukawa M, Tadokoro K, Furumoto M (2009) Is the Ryukyu Subduction Zone in Japan coupled or decoupled? - the necessity of seafloor crustal deformation observation. Earth Planets Space 61:1-9.

Araoka D, Yokoyama Y, Suzuki A, Goto K, Miyagi K, Miyazawa K, Matsuzaki H, Kawahata H (2013) Tsunami recurrence revealed by Porites coral boulders in the southern Ryukyu Islands, Japan. Geology 41:919-922.

Atwater BF (1987) Evidence for great Holocene earthquakes along the outer coast of Washington State. Science 236:942-944.

Cisternas M et al (2005) Predecessors of the giant 1960 Chile earthquake. Nature 437:404-407. https://doi.org/10.1038/nature03943.

Donato S, Reinhardt EG, Boyce Il, Rothaus R, Vosmer T (2008) Identifying paleotsunamis using bivalve shell taphonomy. Geology 36:199-202.

Engel M, Oetjen J, May SM, Brückner H (2016) Tsunami deposits of the Caribbean towards an improved coastal hazard assessment. Earth Science Rev 163:260-296.
Fujiwara O, Masuda F, Sakai T, Irizuki T, Fuse K (2000) Tsunami deposits in Holocene bay mud in southern Kanto region, Pacific coast of central Japan. Sedi Geol 135:219-230.

Fujiwara O, Tanigawa K, Sato S (2014) Molluscan shell concentration by great tsunami : with special reference to the 2011 Tohoku-oki event. Gekkan Earth 36:36-41 (in Japanese).

Goff J, Chagué-Goff C, Nichol S, Jaffe B, Dominey-Howes D (2012) Progress in palaeotsunami research. Sedi Geol 243-244:70-88.

Goto K, Kawana T, Imamura F (2010) Historical and geological evidence of boulders deposited by tsunamis, southern Ryukyu Islands, Japan. Earth Sci Rev 102:77-99.

Goto K, Miyagi K, Imamura F (2013) Localized tsunamigenic earthquakes inferred from preferential distribution of coastal boulders on the Ryukyu Islands, Japan. Geology 41:1139-1142.

Hongo C, Kayanne H (2009) Holocene coral reef development under windward and leeward locations at Ishigaki Island, Ryukyu Islands, Japan. Sed Geo 214:62-73.

Hongo C, Kayanne H (2010) Holocene sea-level record from corals: reliability of paleodepth indicators at Ishigaki Island, Ryukyu Islands, Japan. Palaeo Palaeo Palaeo 287:143-151.

Inoue T, Goto K, Nishimura Y, Watanabe M, lijima Y, Sugawara D (2017) Paleo-tsunam history along the northern Japan Trench: evidence from Noda Village, northern Sanriku coast, Japan. Prog Earth Planet Sci 4:42. https://doi.org/10.1186/s40645017-0158-1

Ishimura D, Miyauchi T (2015) Historical and paleo-tsunami deposits during the last 4000 years and their correlations with historical tsunami events in Koyadori on the Sanriku Coast, northeastern Japan. Prog Earth Planet Sci 2: 16. https://doi.org/10.1186/s40645-015-0047-4.

Iwasaki T (1927) Tsunami damage at each village. J Climatol J.pn 2:1-57 (in Japanese).

Kan H, Kawana T (2006) "Catch-up" of a high latitude barrier reef by back-reef growth during post-glacial sea-level rise, Southern Ryukyus, Japan. Proc. 10th Int. Coral Reef Symp., Naha, Japan, pp 494-503.

Kawana T, Nakata T (1994) Timing of Late Holocene tsunamis originated around the southern Ryukyu Islands, Japan, deduced from coralline tsunami deposits. Jour Geograph Japan 103:352-376 (in Japanese with English abstract).

Kitamura A (2016) Examination of the largest-possible tsunamis (level 2 tsunami) generated along the Nankai and Suruga troughs during the past 4000 years based on studies of tsunami deposits from the 2011 Tohoku-oki tsunami. Prog Earth Planet Sci 3:12. https://doi.org/10.1186/s40645-016-0092-7.

Kitamura A, Ito M, Sakai S, Yokoyama Y, Miyairi Y (2018) Identification of tsunami deposits using a combination of radiometric dating and oxygen-isotope profiles of articulated bivalves. Mar Geol 403:57-61.

Kondo Y, Abbott ST, Kitamura A, Naish T, Kamp PJJ, Kamataki T, Saul GS (1998) The relationship between shellbed type and sequence architecture: examples from Japan and New Zealand. Sedi Geol 122:109-127.

Kondo Y, Yokogawa K (2001) Substrate preferences and burrowing ability of Donacidae and Mesodesmatidae (Bivalvia) on beaches of southwest Japan. Venus 60(1/2):57-69.

Kortekaas S, Dawson A (2007) Distinguishing tsunami and storm deposits: an example from Martinhal, SW Portugal. Sedi Geol 200:208-221.

Machida H, Ota Y, Kawana T, Moriwaki H, Nagaoka S (2001) Geomorphology of Japan 7: Kyusyu and Southwestern Islands. The Univ. Tokyo Press, Tokyo, p 355.

Makino K (1968) The Meiwa tsunami at Yaeyama, p 462 Published by author, Ishigaki (in Japanese)

Mannen K, Yoong KH, Suzuki S, Matsushima Y, Ota Y, Kain CL, Goff J (2018) History of ancient megathrust earthquakes beneath metropolitan Tokyo inferred from coastal lowland deposits. Sedi Geol 364:258-275.

Minoura K, Imamura F, Sugawara D, Kono Y, Iwashita T (2001) The 869 Jogan tsunami deposit and recurrence interval of large-scale tsunami on the Pacific coast of northeast Japan. J Nat Dis Sci 23:83-88.

Monecke K, Finger W, Klarer D, Kongko W, McAdoo BG, Moore AL, Sudrajat SU (2008) A 1,000-year sediment record of tsunami recurrence in northern Sumatra. Nature 455:1232-1234.

Morales JA, Borrego J, San Miguel EG, Lopez-Gonzalez N, Carro BM (2008) Sedimentary record of recent tsunamis in the Huelva Estuary (Southwest Spain). Quat Sci Rev 27:734-746.

Nanayama F, Satake K, Furukawa R, Shimokawa K, Atwater BF, Shigeno K, Yamaki $S$ (2003) Unusually large earthquakes inferred from tsunami deposits along the Kuril trench. Nature 424:660-663.

Nanayama F, Shigeno K (2006) Inflow and outflow facies from the 1993 tsunami in southwest Hokkaido. Sedi Geol 187:139-158.

Nelson AR, Briggs RW, Dura T, Engelhart SE, Gelfenbaum G, Bradley LA, Forman S, Vane CH, Kelley KA (2015) Tsunami recurrence in the eastern Alaska-Aleutian 
arc: a Holocene stratigraphic record from Chirikof Island, Alaska. Geosphere 11:1172-1203.

Ohno T, Katoh T, Yamasu T (1995) The origin of algal-bivalve photo-symbiosis. Palaeontology 38:1-21.

Okutani T (2000) Marine mollusks in Japan. University of Tokyo Press, Tokyo, 1173 pp. Reinhardt EG, Goodman BE, Boyce Jl, Lopez G, van Hengstum P, Rink W, Mart Y, Raban A (2006) The tsunami of 13 December A.D. 115 and the destruction of Herod the Great's harbor at Caesarea Maritima, Israel. Geology 34:1061-1064.

Reinhardt EG, Pilarczyk JE, Brown A (2012) Probable tsunami origin for a shell and sand sheet from marine ponds on Anegada, British Virgin Islands. Nat Hazards 63:101-117.

Richmond BM, Buckley M, Etienne S, Chagué-Goff C, Clark K, Goff J, DomineyHowes D, Strotz L (2011) Deposits, flow characteristics, and landscape change resulting from the September 2009 South Pacific tsunami in the Samoan islands. Earth Sci Rev 107:38-51.

Rubin CM, Horton BP, Sieh K, Pilarczyk JE, Daly P, Ismail N, Parnell AC (2017) Highly variable recurrence of tsunamis in the 7,400 years before the 2004 Indian Ocean tsunami. Nat Commun 8:16019. https://doi.org/10.1038/ ncomms16019.

Sawai Y, Jankaew K, Martin ME, Prendergast A, Choowong M, Charoentitirat T (2009) Diatom assemblages in tsunami deposits associated with the 2004 Indian Ocean tsunami at Phra Thong Island, Thailand. Mar Micro 73:70-79,

Shimajiri K (1988) Historical papers of the large tsunami at Miyako Island. Bull Cult Aff Div Okinawa Prefecture Educ Board 5:1-10 (in Japanese, original title translated).

Shishikura M, Sawai Y, Namegaya Y (2010) Reproduction of mega-tsunami that occurred in Heian period AD 869 Jogan tsunami. AFREC News 16:1-10 (in Japanese).

Sugawara D, Minoura K, Nemoto N, Tsukawari S, Goto K, Imamura F (2009) Foraminiferal evidence of submarine sediment transport and deposition by backwash during 2004 Indian Ocean tsunami. Island Arc 18:513-525.

Sugawara D, Takahashi T, Imamura F (2014) Sediment transport due to the 2011 Tohoku-oki tsunami at Sendai: results from numerical modeling. Mar Geol 358:18-37.

Szczuciński W, Kokociński M, Rzeszewski M, Chagué-Goff C, Cachão M, Goto K, Sugawara D (2012) Sediment sources and sedimentation processes of 2011 Tohoku-oki tsunami deposits on the Sendai Plain, Japan -insights from diatoms, nannoliths and grain size distribution. Sedi Geol 282:40-56.

Takada Y, Kosuge T, Nishihama S, Katoh M (2002) Vertical distributions of Atactodea striata and Latona faba (Bivalvia) on a subtropical sandy beach in Ishigaki Island, Japan. Venus 61(3-4):203-213.

Takashimizu Y, Urabe A, Suzuki K, Sato Y (2012) Deposition by the 2011 Tohokuoki tsunami on coastal lowland controlled by beach ridges near Sendai, Japan. Sed Geo 282:124-141.

Vött A, Lang F, Brückner H, Gaki-Papanastassiou K, Maroukian H, Papanastassiou D, Giannikos A, Hadler H, Handl M, Ntageretzis K, Willershäuser T, Zander A (2011) Sedimentological and geoarchaeological evidence of multiple tsunamigenic imprint on the Bay of Palairos-Pogonia (Akarnania, NW Greece). Quat Int 242:213-239.

Watanabe H (1985) A comprehensive list of tsunami damage in Japan. University of Tokyo Press, Tokyo, p 206.

Yokoyama Y, Maeda Y, Okuno J, Miyairi Y, Kosuge T (2016) Holocene Antarctic melting and lithospheric uplift history of the southern Okinawa trough inferred from mid- to late-Holocene sea level in Iriomote Island, Ryukyu, Japan. Quat Int 397:342-348.

\section{Submit your manuscript to a SpringerOpen ${ }^{\circ}$ journal and benefit from:}

- Convenient online submission

Rigorous peer review

- Open access: articles freely available online

- High visibility within the field

- Retaining the copyright to your article

Submit your next manuscript at $\boldsymbol{\nabla}$ springeropen.com 